\title{
Isolation of an antimicrobial compound produced by bacteria associated with reef-building corals
}

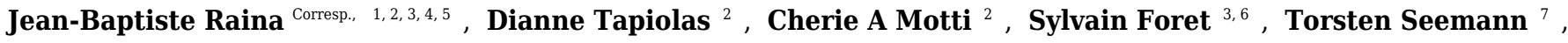 \\ Jan Tebben ${ }^{8,9}$, Bette L Willis ${ }^{3,4}$, David G Bourne ${ }^{2,4}$ \\ ${ }^{1}$ Climate Change Cluster (C3), University of Technology Sydney, Sydney, NSW, Australia \\ 2 Australian Institute of Marine Science, Townsville, QLD, Australia \\ 3 James Cook University, Australian Research Council Centre of Excellence for Coral Reef Studies, Townsville, QLD, Australia \\ 4 Marine Biology and Aquaculture, College of Science and Engineering, James Cook University of North Queensland, Townsville, QLD, Australia \\ 5 James Cook University, AIMS@JCU, Townsville, QLD, Australia \\ 6 Research School of Biology, Australian National University, Canberra, ACT, Australia \\ 7 Victorian Life Sciences Computation Initiative, University of Melbourne, Melbourne, Victoria, Australia \\ 8 Section Chemical Ecology, Alfred Wegener Institute, Bremerhaven, Germany \\ 9 University of New South Wales, Sydney, NSW, Australia \\ Corresponding Author: Jean-Baptiste Raina \\ Email address: Jean-Baptiste.Raina@uts.edu.au
}

Bacterial communities associated with healthy corals produce antimicrobial compounds that inhibit the colonization and growth of invasive microbes and potential pathogens. To date, however, bacteria-derived antimicrobial molecules have not been identified in reefbuilding corals. Here we report the isolation of an antimicrobial compound produced by Pseudovibrio sp. P12, a common and abundant coral-associated bacterium. This strain was capable of metabolizing dimethylsulfoniopropionate (DMSP), a sulfur molecule produced in high concentrations by reef-building corals and playing a role in structuring their bacterial communities. Bioassay-guided fractionation coupled with nuclear magnetic resonance (NMR) and mass spectrometry (MS), identified the antimicrobial as tropodithietic acid (TDA), a sulfur-containing compound likely derived from DMSP catabolism. TDA was produced in large quantities by Pseudovibrio sp., and prevented the growth of two previously identified coral pathogens, Vibrio coralliilyticus and $V$. owensii, at very low concentrations $(0.5 \mu \mathrm{g} / \mathrm{mL})$ in agar diffusion assays. Genome sequencing of Pseudovibrio sp. P12 identified gene homologs likely involved in the metabolism of DMSP and production of TDA. These results provide additional evidence for the integral role of DMSP in structuring coral-associated bacterial communities and underline the potential of these DMSP-metabolizing microbes to contribute to coral disease prevention. 
1 Isolation of an antimicrobial compound produced by bacteria associated with reef-building

2

3

4

7 aJames Cook University, Marine Biology and Aquaculture, College of Science and Engineering,

8 Townsville 4810, QLD, Australia.

9 bAIMS@JCU, James Cook University, Townsville 4810, QLD, Australia

\section{corals}

Jean-Baptiste Raina ${ }^{\mathrm{a}, \mathrm{b}, \mathrm{c}, \mathrm{d}, \mathrm{e}^{*}}$, Dianne M. Tapiolas ${ }^{\mathrm{b}}$, Cherie A. Motti ${ }^{\mathrm{b}}$, Sylvain Forêt ${ }^{\mathrm{d}, \mathrm{f}}$, Torsten Seemann", Jan Tebben ${ }^{\text {c,h,i, }}$ Bette L. Willis ${ }^{\mathrm{a}, \mathrm{d}} \&$ David G. Bourne ${ }^{\mathrm{a}, \mathrm{b}}$

${ }^{\mathrm{c}}$ Australian Institute of Marine Science, Townsville 4810, QLD, Australia.

dAustralian Research Council Centre of Excellence for Coral Reef Studies, James Cook

University, Townsville 4810, QLD, Australia

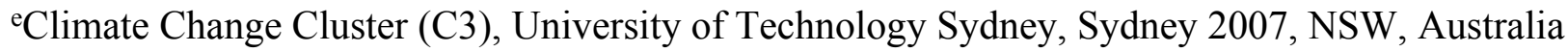

${ }_{\mathrm{f}}^{\mathrm{f}}$ ustralian National University, Research School of Biology, Canberra 2601, ACT, Australia.

gVictorian Life Sciences Computation Initiative, University of Melbourne, Melbourne 3168,

VIC, Australia.

hUniversity of New South Wales, Sydney 2052, NSW, Australia.

${ }^{i}$ Alfred Wegener Institute, Section Chemical Ecology, Bremerhaven 27570, Germany

${ }^{*}$ Corresponding author

Tel: +61295144092

Email: Jean-Baptiste.Raina@uts.edu.au 
25 Abstract

26 Bacterial communities associated with healthy corals produce antimicrobial compounds that

27 inhibit the colonization and growth of invasive microbes and potential pathogens. To date,

28 however, bacteria-derived antimicrobial molecules have not been identified in reef-building corals. Here we report the isolation of an antimicrobial compound produced by Pseudovibrio sp. P12, a common and abundant coral-associated bacterium. This strain was capable of metabolizing dimethylsulfoniopropionate (DMSP), a sulfur molecule produced in high concentrations by reef-building corals and playing a role in structuring their bacterial communities. Bioassay-guided fractionation coupled with nuclear magnetic resonance (NMR) and mass spectrometry (MS), identified the antimicrobial as tropodithietic acid (TDA), a sulfurcontaining compound likely derived from DMSP catabolism. TDA was produced in large quantities by Pseudovibrio sp., and prevented the growth of two previously identified coral pathogens, Vibrio coralliilyticus and $V$. owensii, at very low concentrations $(0.5 \mu \mathrm{g} / \mathrm{mL})$ in agar diffusion assays. Genome sequencing of Pseudovibrio sp. P12 identified gene homologs likely involved in the metabolism of DMSP and production of TDA. These results provide additional evidence for the integral role of DMSP in structuring coral-associated bacterial communities and underline the potential of these DMSP-metabolizing microbes to contribute to coral disease

42 prevention. 
50

51

52

53

54

55

56

57

58

59

60

61

62

63

64

65

66

67

68

69

70

71

\section{Introduction}

Coral reefs are one of the most biologically diverse ecosystems on the planet (Bellwood \& Hughes 2001; Knowlton 2001; Pauley 1997). Each square centimeter of a coral's surface harbors several thousand species of microbes (Sunagawa et al. 2010) and up to $10^{7}$ bacterial cells (Garren \& Azam 2010; Koren \& Rosenberg 2006), an abundance ten times greater, on average, than the surrounding sea water. These microbial assemblages are often highly specific to their coral host and include large numbers of rare and sometimes even unique taxa (Sunagawa et al. 2010). Although the phylogenetic diversity and dynamics of coral-associated bacterial communities have been studied for more than a decade (Bourne \& Munn 2005; Bourne et al. 2013; Littman et al. 2009; Rohwer et al. 2001; Sunagawa et al. 2010), their ecological and functional roles in the biology and health of corals are still poorly understood.

Recent studies have started to unravel the roles that coral-associated bacteria and their interactions with their coral hosts are likely to play within the coral holobiont. For example, some members of the Cyanobacteria, Rhizobiales and Vibrionaceae taxa are likely to fix dissolved nitrogen, a particularly important process in oligotrophic environments such as coral reefs (Lema et al. 2012; Lesser et al. 2004; Olson et al. 2009). Others, like Roseobacter, Pseudomonas and Oceanospirillales, can metabolize dimethylsulfoniopropionate (DMSP), an organic sulfur compound produced in large quantities by corals and suspected to play a role in structuring coral-associated bacterial communities (Raina et al. 2010; Raina et al. 2013). It has also been hypothesized that bacteria act as a line of defense against invasive pathogens, either by competing for space and occupying coral niches (Ritchie \& Smith 2004), or by directly 
72 producing antimicrobial compounds that inhibit the growth of invasive microbes in coral mucus

73 (Ritchie 2006).

74

In artificial culture conditions, approximately $25 \%$ of the cultivable coral bacteria

produce antimicrobial compounds that prevent the growth of pathogenic micro-organisms

(Ritchie 2006; Shnit-Orland \& Kushmaro 2008). Several of these antimicrobial-producing taxa, such as Pseudoalteromonas, Pseudomonas, and the Roseobacter clade are commonly found in association with numerous coral species (Nissimov et al. 2009; Radjasa et al. 2008; Rypien et al. 2010; Shnit-Orland \& Kushmaro 2009). Although the presence of antimicrobial defences in reefbuilding corals has been reported (Geffen et al. 2009; Geffen \& Rosenberg 2005; Gochfeld \& Aeby 2008; Koh 1997), only few active compounds - all produced by the coral animal itself have been isolated to date (Fusetani et al. 1996; Kodani et al. 2013; Vidal-Dupiol et al. 2011). The aim of this study was to identify specific antimicrobial compounds and thereby enhance our understanding of the functional roles played by coral-associated bacteria. Our specific objectives were to: $(i)$ isolate a common coral-associated bacterium with antimicrobial activity and identify the compound(s) responsible for the activity; (ii) evaluate the susceptibility of the coral pathogens Vibrio coralliilyticus and Vibrio owensii to the isolated compound; (iii) determine the effect that thermal stress might have on its production; and (iv) investigate the natural abundance of the antimicrobial compound in coral extracts.

91

\section{Materials and Methods}


Montipora aequituberculata (one colony per species) were collected in November 2011 from

Davies Reef, Great Barrier Reef, Australia (latitude, $18^{\circ} 51^{\prime}$ S; longitude, $147^{\circ} 41^{\prime} \mathrm{E}$, Great Barrier

Reef Marine Park Authority permit G12/35236.1) and maintained in aquaria for 6 days at the

fragments (approximately $25 \mathrm{~mm}$ in length, containing 60 to 70 polyps) were collected from

each colony and washed in sterile artificial seawater (ASW) to remove loosely attached

microbes. Tissue slurries were produced by airbrushing $\left(80 \mathrm{lb} / \mathrm{in}^{2}\right)$ each coral fragment into $5 \mathrm{~mL}$

of ASW to remove coral tissues and associated microbes. These tissue slurries were

homogenized to break down tissue clumps, and a dilution series was plated immediately on

bacteriological agar (1\%) in $1 \mathrm{~L}$ ASW supplemented with $0.3 \%$ casamino acids and $0.4 \%$ into Marine Broth (MB; Difco, BD, Franklin Lakes, NJ) and grown overnight. Liquid cultures were re-plated on minimal marine agar and the procedure was repeated until pure cultures were obtained.

\section{Well diffusion assay with bacterial isolates}

Fifty bacteria isolated from the coral tissue slurries of the 3 species $(A$. millepora $=16, P$.

damicornis $=17$, M. aequituberculata $=17$ ) were tested for growth-inhibitory activity against the

113 known coral pathogens Vibrio coralliilyticus P1 (LMG23696) and V. owensii DY05

114 (LMG25443) in a well diffusion agar assay. In brief, the Vibrio strains were seeded into two

115 different batches of minimal marine agar (after the agar temperature cooled to $40^{\circ} \mathrm{C}$ ). Following 116 solidification, wells (diameter $5 \mathrm{~mm}$ ) were cut into the agar and loaded with $20 \mu \mathrm{L}$ of overnight 
117 cultures $\left(10^{8}\right.$ cells $\left./ \mathrm{ml}\right)$ of the test isolates grown in $\mathrm{MB}\left(28^{\circ} \mathrm{C}, 170 \mathrm{rpm}\right)$. Plates were incubated at

$11828^{\circ} \mathrm{C}$ and monitored every $24 \mathrm{~h}$ for a period of $72 \mathrm{~h}$ for inhibition zones. Phaeobacter strain $27-4$

119 was used as a positive antagonistic control on each plate because of its broad spectrum inhibitory

120 activity against Vibrio (Bruhn et al. 2007; Hjelm et al. 2004).

121

122 DNA extraction, gene sequencing genomic analyses

123 One strain, P12 isolated from Pocillopora damicornis, produced the strongest growth-

124 inhibitory activity against the two target Vibrio strains. High molecular weight genomic DNA

125 from P12 was extracted using a miniprep phenol-chloroform based extraction. Briefly, $5 \mathrm{~mL}$ of

126 overnight liquid culture of P12 $\left(10^{8}\right.$ cells $\left./ \mathrm{ml}\right)$ were spun in a micro-centrifuge $(10,000 \mathrm{rcf})$ for 2

127 min. The pellet was then resuspended in $567 \mu \mathrm{L}$ of TE buffer, $30 \mu \mathrm{L}$ of $10 \%$ SDS and $3 \mu \mathrm{L}$ of 20

$128 \mathrm{mg} / \mathrm{mL}$ proteinase $\mathrm{K}$. The tube was shaken thoroughly and incubated for $1 \mathrm{hr}$ at $37^{\circ} \mathrm{C}$. One

129 hundred microliters of $5 \mathrm{M} \mathrm{NaCl}$ was subsequently added and the sample thoroughly mixed

130 before adding $80 \mu \mathrm{L}$ of $\mathrm{CTAB} / \mathrm{NaCl}(10 \% \mathrm{CTAB}$ in $0.7 \mathrm{M} \mathrm{NaCl})$. The solution was incubated

131 for $10 \mathrm{~min}$ at $65^{\circ} \mathrm{C}$, extracted with an equal volume of phenol/chloroform/isoamyl alcohol and

132 centrifuged for 10 mins (10,000 rcf). The supernatant was then extracted with an equal volume

133 of chloroform/isoamyl alcohol and centrifuged again for $10 \mathrm{~min}$. The aqueous phase was

134 transferred to a new tube, DNA precipitated with equal volume of ice-cold isopropanol, washed 135 with $70 \%$ ethanol and dried.

136 The near complete 16S rRNA gene of the strain was PCR amplified with bacterial

137 specific primers 63F and 1387R, as outlined in Marchesi et al. (Marchesi et al. 1998). Amplified

138 PCR products were visualized by electrophoresis on 1\% agarose gel stained with ethidium

139 bromide. The amplified DNA was dried in a vacuum centrifuge (Savant DNA 120) and 
140 sequenced (Macrogen, Inc., Seoul, Korea). The 16S rRNA gene sequence of isolate P12 was

141 used for phylogenetic comparisons and Maximum Likelihood trees were constructed using the

142 ARB software.

143 We produced a draft genome assembly of P12. A paired-end library was prepared using

144 the Illumina Truseq protocol (Illumina, San Diego, CA, USA), with an insert size of $169 \mathrm{bp}$ and

145 a read size of 150 bp. The library was sequenced on an Illumina MiSeq instrument at Monash

146 University (Melbourne, Australia). The genome was assembled with the SPAdes assembler

147 (v2.4.0) (Bankevich et al. 2012) and annotated with the Prokka software (v1.5.2) (Seeman 2014).

148 The presence of the genes involved in DMSP metabolism $(d m d A, d d d D, d d d L, d d d P, d d d Y$,

$149 d d d Q, d d d W)$ and TDA production (tdaA-tdaH) was investigated by searching for homologs of

150 the corresponding genes using reciprocal best blast hits.

151

152 DMSP metabolic capabilities of the isolate P12

153 Two different minimal media were used to examine the DMSP metabolic capabilities of

154 P12: a modified marine ammonium salt medium (MAMS) (Raina et al. 2009) lacking a carbon

155 source, and a modified basal salt medium lacking a sulfur source (Fuse et al. 2000) (25 g of

$156 \mathrm{NaCl}, 0.7 \mathrm{~g}$ of $\mathrm{KCl}, 0.05 \mathrm{~g}$ of $\mathrm{KH}_{2} \mathrm{PO}_{4}, 1 \mathrm{~g}$ of $\mathrm{NH}_{4} \mathrm{NO}_{3}, 0.2 \mathrm{~g}$ of $\mathrm{MgCl}_{2} \cdot \mathrm{H}_{2} \mathrm{O}, 0.02 \mathrm{~g}$ of

$157 \mathrm{CaCl}_{2} \cdot 2 \mathrm{H}_{2} \mathrm{O}, 0.005 \mathrm{~g}$ of FeEDTA, $1 \mathrm{~g}$ of Tris, $5 \mathrm{~g}$ of sodium succinate, $1.35 \mathrm{~g}$ of glucose in $1 \mathrm{~L}$

158 of distilled water). DMSP was added to both media (1 mM), acting either as the sole carbon or

159 sulfur source. Five milliliters of each culture media were inoculated in triplicate with single P12

160 colonies and incubated at $28^{\circ} \mathrm{C}$ for 6 days. Negative controls containing only the basal media and

161 DMSP were used to account for possible chemical breakdown of DMSP. Bacterial growth was

162 assessed via optical density measurement (NanoDrop, Thermo Fisher, Waltham, MA). DMSP 
163 metabolism was assessed by ${ }^{1} \mathrm{H}$ Nuclear Magnetic Resonance spectroscopy (NMR). Methanol

$164\left(\mathrm{CH}_{3} \mathrm{OH} ; 40 \mathrm{~mL}\right)$ was added to each culture tube, the mixture shaken vigorously and sonicated

165 for 10 mins before being dried in vacuo using a rotary evaporator (Buchi, Flawil, Switzerland).

166 The dried extracts were resuspended in a mixture of deuterium oxide $\left(\mathrm{D}_{2} \mathrm{O} ; 250 \mu \mathrm{L}\right)$ and

167 deuterated methanol $\left(\mathrm{CD}_{3} \mathrm{OD} ; 750 \mu \mathrm{L}\right)$ (Cambridge Isotope Laboratories, Andover, MA, USA).

168 A 750-mL aliquot of the particulate-free extract was transferred into a 5-mm Norell tube (Norell

169 Inc., Landisville, NJ, USA) and analyzed immediately using quantitative NMR (Tapiolas et al.

170 2013).

171

172

Preparation of crude extracts for antagonist assays

173 An overnight culture of P12 $(8 \mathrm{~mL})$ was used to inoculate $4 \times 250 \mathrm{~mL}$ of MB (total culture

174 volume $=1 \mathrm{~L})$. Bacterial cells were incubated for two days at $28^{\circ} \mathrm{C}(120 \mathrm{rpm})$; the culture broth

175 was then acidified to $\mathrm{pH} 2$ with sulphuric acid before being exhaustively extracted with ethyl

176 acetate $(3 \times 1.5 \mathrm{~L})$. The extract was washed three times with MilliQ $\mathrm{H}_{2} \mathrm{O}$ and dried in vacuo

177 using a rotary evaporator (Buchi). The dried extract was then weighed and resuspended in

$178 \mathrm{CH}_{3} \mathrm{OH}$ (which was chosen for its ability to solubilize a wide range of compounds, its volatility

179 and its innocuity in small volume towards both $V$. coralliilyticus and $V$. owensii) and tested in

180 well-diffusion assays to confirm the extraction of the antimicrobial compound(s).

181

182 Purification and characterization of active compound

183 Purification of the crude extract was carried out using solid phase extraction on a

184 reversed phase $\mathrm{C}_{18}$ flash vacuum column (Septra $\mathrm{C}_{18}-\mathrm{E}$, Phenomenex, Torrance, CA, USA).

185 Eleven fractions were eluted sequentially with $20 \%, 40 \%, 60 \%, 80 \%, 90 \% \mathrm{CH}_{3} \mathrm{OH}$ in $\mathrm{H}_{2} \mathrm{O}$ and 
$186100 \% \mathrm{CH}_{3} \mathrm{OH}$, followed by $20 \%, 50 \%$ and $100 \%$ dichloromethane $\left(\mathrm{CH}_{2} \mathrm{Cl}_{2}\right)$ in $\mathrm{CH}_{3} \mathrm{OH}, 40 \%$

187 hexane in $\mathrm{CH}_{2} \mathrm{Cl}_{2}$ and finally $100 \%$ hexane. Each fraction was dried and resuspended in $\mathrm{CH}_{3} \mathrm{OH}$

$188\left(1 \mathrm{mg} \mathrm{mL}^{-1}\right)$. Well diffusion assays were prepared as described above. On each plate, test wells

189 were inoculated with $20 \mu \mathrm{L}$ of each chromatographic fraction, or $20 \mu \mathrm{L}$ of $\mathrm{CH}_{3} \mathrm{OH}$ as a control,

190 and Vibrio growth monitored. The most active faction $\left(80 \% \mathrm{CH}_{3} \mathrm{OH}\right)$ presented an intense

191 yellow color. Fine orange-red needles were crystallized from this active fraction to yield

192 compound 1 (2.1 mg, $1.7 \%$ dry weight of organic extract).

NMR and FTMS analysis

Identification and structural elucidation of compound $\mathbf{1}$ was achieved using liquid

chromatography - mass spectrometry (LC-MS), NMR, and Fourier Transform mass spectrometry

(FTMS). Likewise these techniques were used to monitor for the presence of compound $\mathbf{1}$ in extracts and fractions. LC-MS analyses were performed on a Thermo Fisher Scientific Ultra

High Performance Liquid Chromatography system connected to an LTQ Orbitrap XL mass

UPLC BEH RP-C ${ }_{18}$ column (130A, $1.7 \mu \mathrm{m}, 2.1 \mathrm{~mm}$ x $100 \mathrm{~mm}$, solvents $\mathrm{A}=$ aqueous $0.1 \%$

formic acid and $\mathrm{B}=$ acetonitrile, gradient elution $80 \% \mathrm{~A}: 20 \% \mathrm{~B}$ for $0.5 \mathrm{~min}$ ramped up to $100 \%$

B over $10 \mathrm{~min}$, then held for $4 \mathrm{~min}, 400 \mu \mathrm{L}$ ) and detected by positive mode electrospray ionisation using two different $\mathrm{m} / \mathrm{z}$ ranges: $150-1500$ and $170-400 .{ }^{1} \mathrm{H}$ and ${ }^{13} \mathrm{C}$ NMR spectra of compound 1 were acquired in a 5 mm 509-UP Norell NMR tube on a Bruker Avance $600 \mathrm{MHz}$

NMR spectrometer (Bruker, Germany) with a TXI cryoprobe using standard Bruker pulse sequences. NMR spectra were referenced to residual ${ }^{1} \mathrm{H}$ and ${ }^{13} \mathrm{C}$ resonances in deuterated 
209 BioApex 47e Fourier Transform Mass Spectrometer (FTMS) fitted with an Analytica of

210 Branford ESI source; ions were detected in negative mode within a mass range $\mathrm{m} / \mathrm{z} 200-1,000$ via

211 direct infusion at $120 \mu \mathrm{lh}^{-1}$.

212

213

Temperature-dependent activity

214

The antimicrobial activity of $\mathrm{P} 12$ grown at $32^{\circ} \mathrm{C}$ (upper limit of coral thermal tolerance)

215

216

217

218

219

220

221

222

223

224

225

226

227

228

229

230

231

was compared to that of the control incubated at $28^{\circ} \mathrm{C}$. The two cultures were grown overnight in

$\mathrm{MB}$ at the two different temperatures, and their densities were determined by flow-cytometry

(BD Accuri C6, Beckman Coulter, Brea, CA). Cell numbers were normalized prior to

inoculation into agar wells, and their activities against the two pathogens were compared using well-diffusion assays as described above. The same procedure was repeated with compound 1: two vials containing equal concentrations $\left(2 \mu \mathrm{M}\right.$ of $\mathbf{1}$ in $\left.\mathrm{CH}_{3} \mathrm{OH}\right)$ were incubated overnight at $28^{\circ} \mathrm{C}$ or $32^{\circ} \mathrm{C}$ and their antimicrobial activities compared using the well diffusion assay.

\section{Preparation of coral extracts}

The coral species Montipora aequituberculata, M. turtlensis, Pocillopora damicornis, Acropora millepora, and Porites cylindrica (one colony each; $500 \mathrm{~g}$ of dry skeleton per species) were collected in July 2012 from Orpheus Island, Great Barrier Reef, Australia (latitude, $18^{\circ} 35^{\prime}$ S; longitude, $146^{\circ} 20^{\prime} E$, Great Barrier Reef Marine Park Authority permit G12/35236.1). Coral tissues were airbrushed $\left(80 \mathrm{lb} / \mathrm{in}^{2}\right)$ into $1 \mu \mathrm{m}$ filtered seawater $(\mathrm{FSW})($ total volume $=500$ $\mathrm{mL}$ ), acidified to $\mathrm{pH} 2$ with sulphuric acid and the solution exhaustively extracted with equal volumes of ethyl acetate $(3 \times 750 \mathrm{~mL})$. The combined organic layers were partitioned with MilliQ $\mathrm{H}_{2} \mathrm{O}$, dried and tested in well-diffusion assays, as previously described for the bacterial 
232 isolate extracts. The extracts of those coral species that exhibited antimicrobial activity were

233 subsequently fractionated as described above for the crude extract from P12 and tested in well-

234 diffusion assays. The active fractions were analyzed using ${ }^{1} \mathrm{H}$ NMR, FTMS and LC-MS.

235

236

237

238

239

240

241

242

243

244

245

246

247

248

249

250

251

252

253

254

8

\section{Results}

Isolate P12: antimicrobial production, taxonomy and metabolic capabilities

A total of 50 coral-associated bacterial isolates were obtained from tissue slurry homogenates of the three coral species. Twelve of the 50 strains tested against the two pathogenic Vibrios (V. coralliilyticus and $V$. owensii) inhibited their growth in well diffusion assays. The bioactive isolate that exhibited the strongest in vitro activity against both pathogens, isolate P12, originated from Pocillopora damicornis and produced growth inhibition zones of 5 $\mathrm{mm}( \pm 0.07 \mathrm{~mm}, n=20)$ against $V$. owensii and $2 \mathrm{~mm}( \pm 0.09 \mathrm{~mm}, n=20)$ against $V$. coralliilyticus. The activity of P12 was temperature-dependent (Figure 1 A-B) and was significantly reduced when grown at $32^{\circ} \mathrm{C}$ compared to $28^{\circ} \mathrm{C}$ (Unpaired T-Test, $n=20, \mathrm{df}=38, t=30.61,{ }^{*} p<0.001$ for $V$. owensii and $n=20, \mathrm{df}=38, t=10.49,{ }^{*} p<0.001$ for $V$. coralliilyticus; Figure $\left.1 \mathrm{C}\right)$. Based on its bioactivity, the isolate P12 was selected for bioassay-guided fractionation.

According to its 16S rRNA gene sequence (NCBI accession number: KX198136), isolate P12 is an alphaproteobacterium belonging to the Rhodobacteraceae family and the Pseudovibrio genus. Its most closely related species is Pseudovibrio denitrificans (100\% identity to the type strain; Figure 2). Like other P. denitrificans strains (Enticknap et al. 2006), P12 colonies formed brown mucoid colonies when grown on Marine Agar. The brown color was absent when the strain was grown on minimal marine agar, with colonies appearing white. This strain was able 
255 use DMSP as either a sole carbon or sole sulfur source (Figure 3). The complete utilization of

256 DMSP from the liquid media after 2 to 3 days of incubation, as well as the presence of its

257 metabolic byproduct dimethylsulfide (DMS), were confirmed by ${ }^{1} \mathrm{H}$ NMR. However acrylate,

258 another possible byproduct of DMSP metabolism, was not observed.

259

260

Among the seven different DMSP degradation pathways currently identified (Moran et

261

al. 2012), the full DMSP cleavage pathway ( $d d d D, d d d B, d d d C$, $d d d T$, $d d d R$; Table 1), involved

262

in the conversion of DMSP into DMS without formation of acrylate (Todd et al. 2007) (Table 1),

was identified in P12. We also identified possible orthologs for the demethylation pathway

( $d m d A, d m d B, d m d C$ and $d m d D)$ used by marine bacteria to assimilate sulfur from DMSP,

though these gene have low sequence identity to the genes originally identified in Ruegeria

pomeroyi DSS-3 (Howard et al. 2006; Reisch et al. 2011) (Table 1). The presence of these two

267

268

269

270

271

272

273

274

275

276

277

gene pathways corroborates the ${ }^{1} \mathrm{H}$ NMR measurements: the observed production of DMS

without acrylate formation following DMSP metabolism (DddD pathway); and the ability to use

DMSP as sole sulfur source (DmdA pathway) (Table 1).

\section{Identification of antimicrobial compounds produced by $P 12$}

Well diffusion assays revealed that the crude extract from P12 retained the antimicrobial properties of the strain against both Vibrio species. Purification of the active fractions using reverse phase liquid chromatography yielded compound 1: optically inactive orange-red crystals;

$2.1 \mathrm{mg}\left(1.7 \%\right.$ dry weight); IR (film) $v_{\max } 3420,1660,1280 \mathrm{~cm}^{-1} ; \mathrm{UV}\left(\mathrm{PDA}, \mathrm{CH}_{3} \mathrm{OH}\right) \lambda_{\max } 512$ $\mathrm{nm} ;{ }^{1} \mathrm{H}$ NMR spectrum (600 MHz, $\left.\mathrm{CD}_{3} \mathrm{Cl}\right): \delta 7.12,7.44,7.45$ and $16.7 ;{ }^{13} \mathrm{C}$ NMR $(150 \mathrm{MHz}$, $\left.\mathrm{CD}_{3} \mathrm{Cl}\right): \delta 120.3,132.0,136.0,138.7,149.5,168.7,171.7$, and 183.5; HRESIMS $m / z$ found 
278210.9534 (calculated for $\mathrm{C}_{8} \mathrm{H}_{3} \mathrm{O}_{3} \mathrm{~S}_{2}-210.9529, \Delta 2 \mathrm{ppm}$ ). Combined spectroscopic techniques

279 revealed that compound 1 was tropodithietic acid (TDA) (Brinkhoff et al. 2004; Penesyan et al. 280 2011) (Figure 4A).

281

282

Orthologs for 11 genes involved in TDA biosynthesis (Geng et al. 2008) were present in

283

284

285

286

287

288

289

290

291

292

293

294

295

296

297

298

299

the Pseudovibrio sp. P12 genome (Table 1). The biosynthesis of TDA correlated with production of the yellow-brown pigmentation in the culture medium and antimicrobial activity, similar to that previously reported (Brinkhoff et al. 2004; Bruhn et al. 2005; Porsby 2010). Both coral pathogens were highly sensitive to TDA, with the pure compound still visually inhibiting their growth at $0.5 \mu \mathrm{g} / \mathrm{mL}(2.35 \mu \mathrm{M}$; Figure 4B). In contrast to the decrease in antimicrobial activity exhibited by Pseudovibrio sp. P12 after incubation at $32^{\circ} \mathrm{C}$, TDA activity was not affected by exposure to this temperature (Unpaired T-Test, $n=20, \mathrm{df}=38, t=-0.94, p=0.355$ for $V$. owensii and $n=20, \mathrm{df}=38, t=0.632, p=0.531$ for $V$. coralliilyticus; Figure $1 \mathrm{~B}-\mathrm{C})$.

\section{Investigating the presence of TDA in coral samples}

All of the extracts derived from the coral species investigated exhibited antimicrobial activity against the two pathogens, with the inhibition zones for P. cylindrica, $M$. aequituberculata, $M$. turtlensis and $P$. damicornis ranging from 3 to $5 \mathrm{~mm}$ in radius whilst the inhibition zones for $A$. millepora were much smaller (1 mm on average). ${ }^{1} \mathrm{H}$ NMR, LC-MS and

FTMS analyses of the extracts and the active fractions of all coral species did not confirm the presence of TDA. The purified TDA could be detected by LC-MS in femtomolar concentrations when the coral fractions were artificially spiked, indicating that this lack of detection was not due 
300 to preferential ionization. Thus, TDA was either not present in the coral fractions tested or in 301 concentrations below the LC-MS detection threshold.

302

303

\section{Discussion}

While previous studies have identified corals as a source of bacteria with antimicrobial

305

306

307

308

309

310

311

312

313

314

315

316

317

318

319

320

321

The strain P12 strongly inhibited the growth of Vibrio coralliilyticus and V. owensii, two coral pathogens causing white syndrome (a collective term describing rapidly progressing tissue loss, exposing band-like areas of white skeleton) (Ben-Haim et al. 2003; Sussman et al. 2008; Ushijima et al. 2012; Willis et al. 2004). Vibrio coralliilyticus exhibits antimicrobial resistance to a wide range of commercial antibiotics and is also resistant to the activities of a large number of coral-associated bacteria (Rypien et al. 2010; Shnit-Orland \& Kushmaro 2009; Vizcaino et al. 2010). Its resistance to commercial antibiotics is considerably greater than that of other marine pathogens such as $V$. parahaemolyticus or $V$. vulnificus, and may contribute to its competitive advantage within the coral holobiont, as well as its ability to infect corals (Vizcaino et al. 2010). 
322 However, whilst $V$. coralliilyticus is resistant to many coral-associated bacteria, its growth was

323 strongly inhibited by the strain P12, emphasizing its antimicrobial capabilities.

324

325

326

327

328

329

330

331

332

333

334

335

336

337

338

339

340

341

342

343

344 8

The isolate P12 belongs to the bacterial genus Pseudovibrio (Shieh et al. 2004), and is ubiquitously found in association with healthy sponges (Enticknap et al. 2006; Thiel \& Imhoff 2003; Webster \& Hill 2001) and corals (see Table 2). Pseudovibrio are thought to be involved in symbiotic relationships with various organisms; they are vertically transmitted in large densities by adult sponges to their larvae (Enticknap et al. 2006) and their presence is required for the growth of the sulfur-oxidizing bacteria Beggiatoa in culture (Bondarev et al. 2013). Furthermore, their genome is organized similarly to that of Rhizobia, a well-characterized symbiotic bacterium (Bondarev et al. 2013; Enticknap et al. 2006; Kennedy et al. 2009). The full genome sequences of Pseudovibrio FO-BEG1 (KEGG genome T01669; isolated from a Caribbean coral, and sharing $100 \%$ sequence similarity with P12 based on its $16 \mathrm{~S}$ rRNA gene sequence) reveal the presence of genes involved in host-cell adhesion, interactions with eukaryotic cell machinery, and production of secondary metabolites (Bondarev et al. 2013), further suggesting that this bacterium is involved in symbiotic relationships with its hosts.

The Pseudovibrio genus is also known for its antimicrobial properties, especially against human pathogens such as Mycobacterium tuberculosis, Bacillus cereus, Yersinia enterocolitica, Listeria monocytogenes or methicillin-resistant Staphylococcus aureus (O'Halloran et al. 2011; Sulistiyani et al. 2010). To date, three active compounds have been isolated from different Pseudovibrio strains: heptylprodigiocin in tunicate-associated P. denitrificans Z143-1 (Sertan-de Guzman et al. 2007), pseudovibrocin in P. denitrificans strain PaH3.28 (Vizcaino 2011) and 
345 tropodithietic acid (TDA) from red alga-associated P. ascidiaceicola D323 (Penesyan et al.

346 2011). In the present study, we isolated TDA from P12, a strain closely related to $P$.

347 denitrificans. The ability of P12 to produce TDA was further supported by the the presence of

348 the genes essential for TDA biosynthesis in the genome of strain P12 (Geng et al. 2008). TDA

349 inhibits the growth of a wide range of marine pathogens (Bruhn et al. 2007; Bruhn et al. 2005)

350 and is produced almost exclusively by bacteria from the Roseobacter clade, especially the genera

351 Phaeobacter, Silicibacter, and Ruegeria (Brinkhoff et al. 2004; Bruhn et al. 2005; Geng \& Belas

352 2010; Geng et al. 2008; Wilson et al. 2016) that are commonly associated with DMSP-producing

353 dinoflagellates (Miller et al. 2004; Wagner-Dobler \& Biebl 2006) and reef-building corals

354 (Bourne et al. 2013; Littman et al. 2009; Raina et al. 2009).

355

356 Many members of the Roseobacter clade, including coral-associated isolates, have been

357 implicated in sulfur cycling (Miller et al. 2004; Moran et al. 2003; Raina et al. 2010).

358 Interestingly, TDA contains two sulfur atoms $\left(\mathrm{C}_{8} \mathrm{H}_{4} \mathrm{O}_{3} \underline{\mathrm{S}}_{2}\right)$ and Pseudovibrio sp. P12 was able to

359 use DMSP either as sole carbon or sole sulfur source, a common trait among

360 Alphaproteobacteria and especially the Roseobacter clade (Bruhn et al. 2005; Wagner-Dobler \&

361 Biebl 2006). Bacteria from this clade preferentially metabolize DMSP rather than sulphate $\left(\mathrm{SO}_{4}{ }^{2-}\right.$

362 ), despite the latter being between $10^{6}$ to $10^{7}$-fold more abundant in seawater (Geng \& Belas

363 2010; Kiene et al. 1999). Based on genomic and chemical analyses, DMSP metabolism in P12

364 could occur via two likely routes: the cleavage pathway (encoded by $d d d D$, (Todd et al. 2007))

365 that releases the climate-regulating molecule DMS, and the demethylation pathway (encoded by

$366 d m d A$, (Howard et al. 2006)) by which the bacterium can retain the sulfur contained in DMSP

367 molecules. 

into the TDA molecule has not been clearly identified. It has been proposed that sulfur et al. 2005; Geng \& Belas 2010; Porsby 2010; Wagner-Dobler \& Biebl 2006). For example,

DMSP increases TDA synthesis two-fold in comparison to other sulfur sources (Geng \& Belas 2010), suggesting that DMSP is a preferred source of sulfur for TDA biosynthesis. Even though other sources of sulfur, such as the amino-acids cysteine and methionine present in artificial media like Marine Broth, might be used to synthesize TDA (Geng \& Belas 2010), DMSP is by far the most readily available reduced sulfur source in the marine environment (Simo 2001). It is therefore likely that in DMSP-rich environments, such as reef-building corals, DMSP metabolism provides the sulfur needed to produce TDA via the demethylation pathway (Howard et al. 2006). aequituberculata, M. turtlensis, Pocillopora damicornis, and Porites cylindrica) could not be confirmed. Three possibilities can explain this lack of detection: (i) TDA is not synthesized in corals; (ii) TDA is present in corals in concentrations below the detection limit of our instruments (which would imply that this compound has a very limited role in coral defense);

390 (iii) our sampling effort was not sufficient. Indeed, we only sampled one colony per species, 
391 from a location more than $100 \mathrm{~km}$ away from the site where the TDA-producing bacteria was

392 isolated and without prior characterization of the bacterial communities present in the colony

393 sampled. Given that TDA-producing Roseobacters are among the first bacteria to colonize the

394 surface of marine microalgae and corals (Apprill et al. 2009; Dang \& Lovell 2000; Miller et al.

395 2004) and can be highly abundant in some coral species (Raina et al. 2009), it would be

396 premature to rule out possible TDA biosynthesis in corals.

397

The activity of P12 against $V$. coralliilyticus sharply decreased at elevated temperatures

$399\left(32^{\circ} \mathrm{C}\right)$, however, the activity of the purified TDA did not. This reveals that the loss of

400

401

402

403

404

405

406

407

408

409

410

411

412

413

antimicrobial activity observed for $\mathrm{P} 12$ at $32^{\circ} \mathrm{C}$ is not due to thermal sensitivity of TDA but likely to a decrease in its production. Our results are in line with previously reported decline in the antibacterial activity of other TDA-producing Roseobacter with temperature increase (Bruhn et al. 2005). Clear links have previously been identified between warm thermal anomalies and outbreaks of white syndromes (Bruno et al. 2007; Heron et al. 2010; Maynard et al. 2011). If indeed TDA is synthesized in vivo, a decrease in its production during anomalously high seawater temperatures could facilitate pathogen outbreaks in corals following thermal stress, especially since the virulence of some disease-causing bacteria (i.e. $V$. coralliilyticus) increase at $32^{\circ} \mathrm{C}$ (Sussman et al. 2008).

This study demonstrates that a common coral-associated bacterium, Pseudovibrio sp. P12, produces TDA, a potent antimicrobial compound that inhibits the growth of marine and coral pathogens, including $V$. coralliilyticus. The bacterium can use DMSP as a sole sulfur or carbon source and potentially as a precursor in the biosynthesis of TDA. The production of TDA 
414 by Pseudovibrio sp. P12 is greatly reduced at temperatures causing thermal stress in corals,

415 potentially providing a window of opportunity for the growth of pathogens. These results provide

416 additional evidence for the integral role of DMSP in structuring healthy, coral-associated

417 bacterial communities and suggest that these DMSP-metabolizing communities may contribute

418 to the prevention of coral diseases.

419

420 Acknowledgments

421 The authors would like to thank E. Botté, C. Gao and M. Garren for their laboratory assistance.

422

423

424

425

426

427

428

429

430

431

432

433

434

435 Figures 

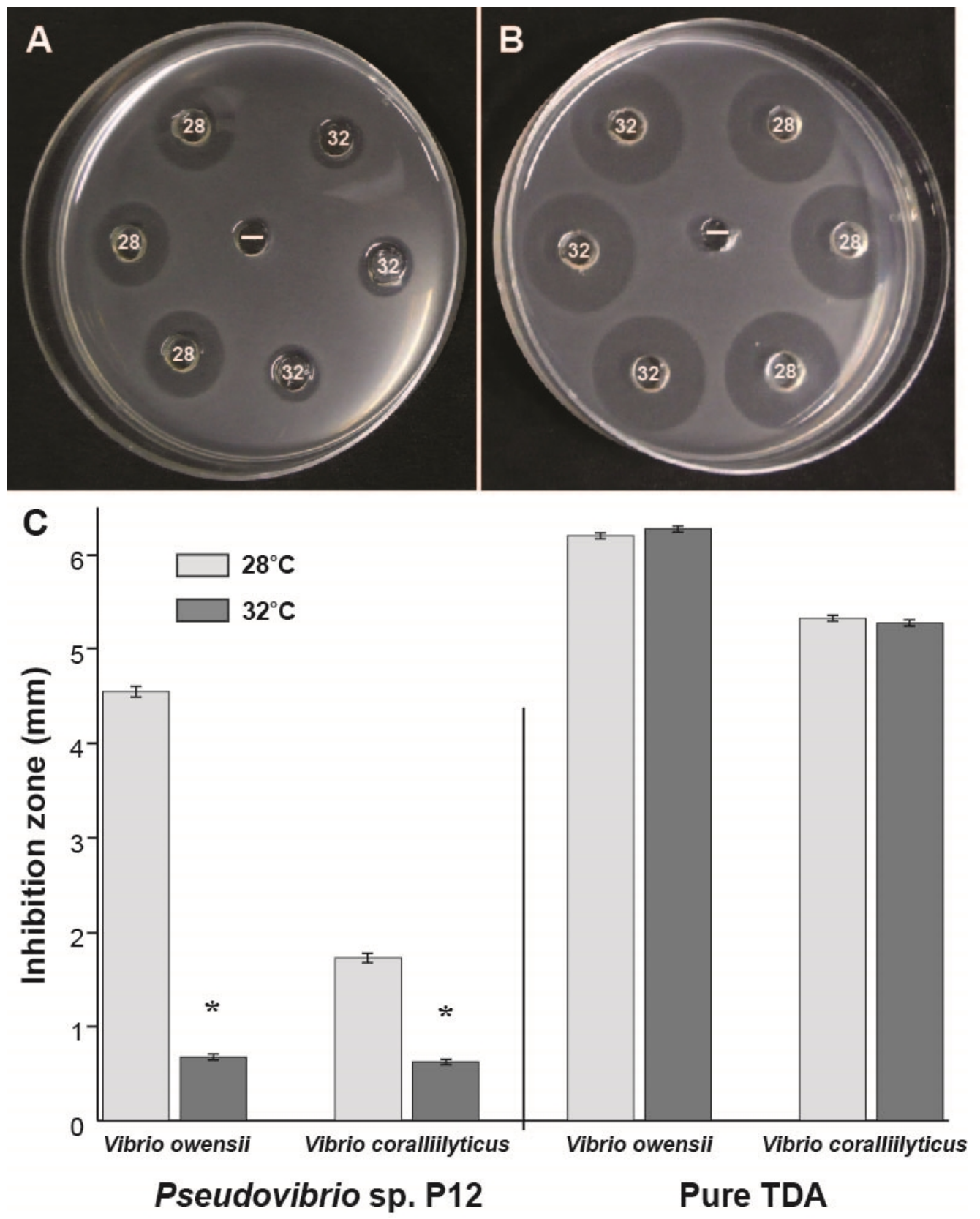

Figure 1: Representative well diffusion assays of $(A)$ Pseudovibrio sp. P12 and $(B)$ pure TDA, incubated at two different temperatures $\left(28^{\circ} \mathrm{C}\right.$ and $\left.32^{\circ} \mathrm{C}\right)$ and then inoculated onto agar plates with embedded Vibrio owensii [(-) Negative control]. (C) Comparison of the radius of inhibition zones between the two temperature treatments for both Pseudovibrio sp. P12 (Unpaired T-Test, $n=20, \mathrm{df}=38, t=30.61,{ }^{*} p<0.001$ for $V$. owensii and $n=20, \mathrm{df}=38, t=10.49,{ }^{*} p<0.001$ for $V$. coralliilyticus $)$ and pure TDA $(2 \mu \mathrm{M}$, Unpaired T-Test, $n=20, \mathrm{df}=38, t=-0.94, p=0.355$ for $V$. owensii and $n=20, \mathrm{df}=38, t=0.632, p=0.531$ for $V$. coralliilyticus ). 


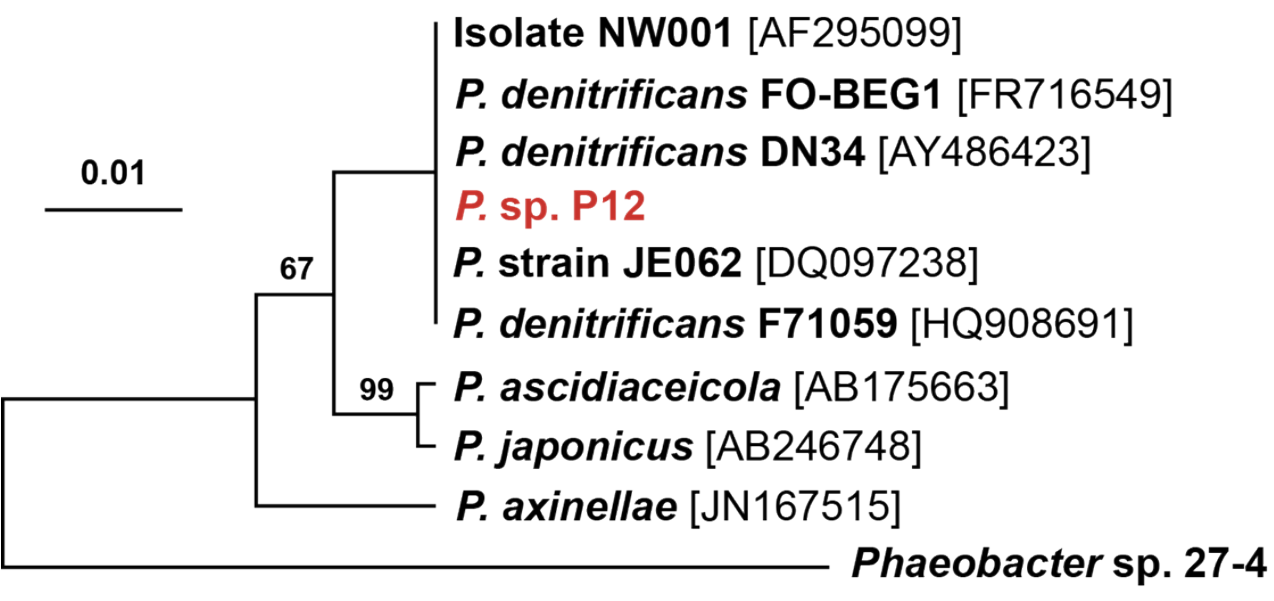

Figure 2: Maximum likelihood phylogenetic tree based on 16S rRNA gene sequences showing the isolate used in this study (P12 in red) and closely associated Pseudovibrio spp. Note: the strain FO-BEG1 has been fully sequenced. Phaeobacter sp. 27-4 [AJ536669] was used as outgroup. Maximum parsimony bootstrap values (10,000 replicates) are given when different from 100. The scale bar indicates the number of substitution per nucleotide position. 

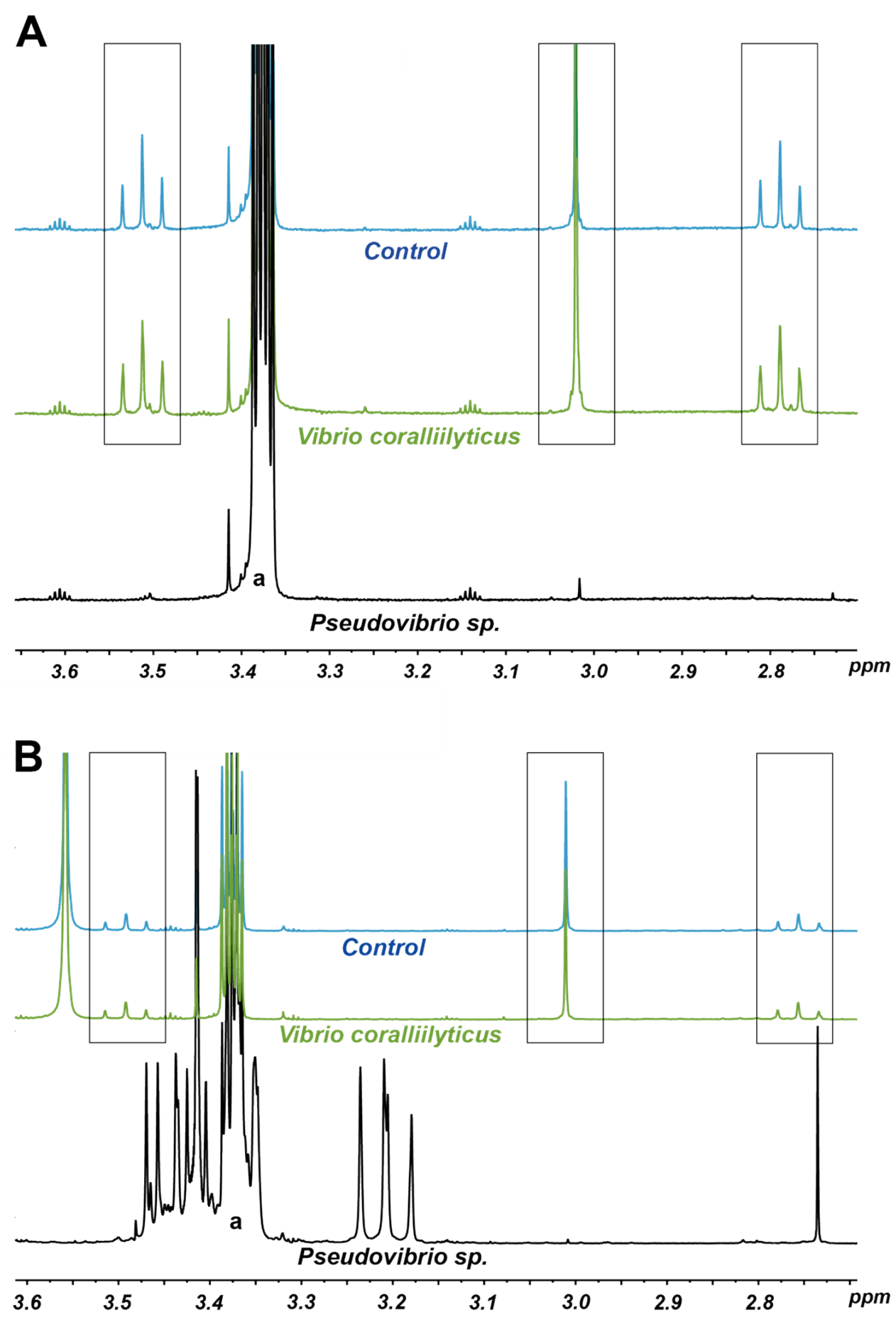

Figure 3: ${ }^{1} \mathrm{H}$ NMR spectra showing DMSP utilization as $(A)$ sole carbon source and $(B)$ sole sulfur source in minimal media at the end of a 6-day incubation. The "control" lines in all cases are the growth medium (with no bacterial inoculation). The black and green spectra show the results from inoculation with Pseudovibrio sp. P12 and V. coralliilyticus (negative control), respectively. In both cases, the DMSP signals (within the three boxes, see (Tapiolas et al. 2013)) disappeared in the Pseudovibrio treatment and remain unchanged between the no-bacteria 
463 control and the $V$. coralliilyticus treatment. In the case of DMSP as a sole sulfur source, 464 Pseudovibrio consumed the DMSP and other carbon sources present and produced secondary 465 metabolites (appearance of new signals). a: solvent peak (methanol).
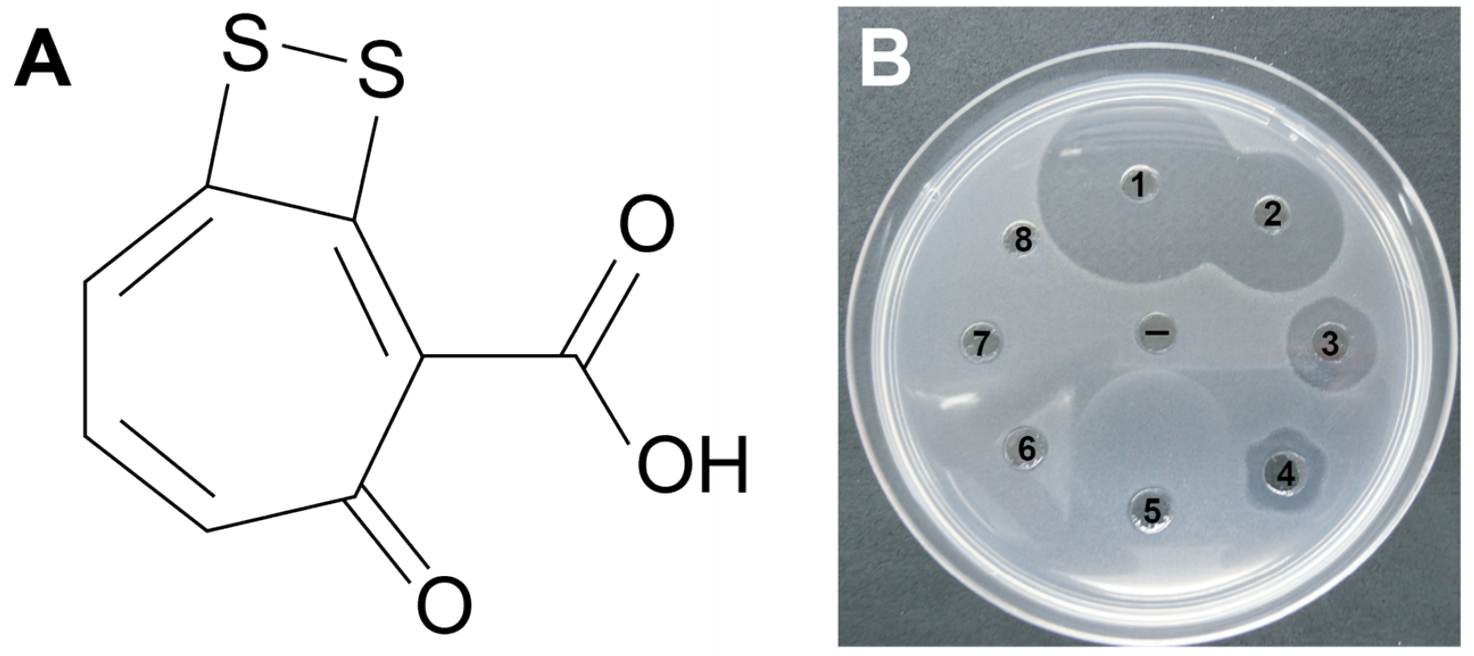

467 Figure 4: $(A)$ Tropodithietic acid (TDA). (B) Dilution series of pure TDA, showing zones of 468 growth inhibition against Vibrio coralliilyticus: [(1): $500 \mu \mathrm{g} / \mathrm{mL},(2): 50 \mu \mathrm{g} / \mathrm{mL},(3): 5 \mu \mathrm{g} / \mathrm{mL}$, 469 (4): $500 \mathrm{ng} / \mathrm{mL},(5): 50 \mathrm{ng} / \mathrm{mL},(6): 5 \mathrm{ng} / \mathrm{mL},(7): 500 \mathrm{pg} / \mathrm{mL},(8): 50 \mathrm{pg} / \mathrm{mL},(-)$ negative control 470 with solvent only]. 
491

492

493

494

495

496

497

498

499

500

501

502

503

Table 1: Orthologous genes involved in DMSP degradation and TDA biosynthesis in Pseudovibrio sp. P12 genome. Accession numbers available in NCBI (http://www.ncbi.nlm.nih.gov/genbank/). Percent of similarity compared to a Marinomonas sp. MWY11 (Todd et al. 2007); ${ }^{b}$ Ruegeria pomeroyi DSS-3 (Reisch et al. 2011); ${ }^{\mathrm{c}}$ Pseudovibrio sp. FO-BEG1 (Alcolombri et al. 2015); ${ }^{\mathrm{d}}$ Phaeobacter inhibens (Brock et al. 2014); ${ }^{\mathrm{e}}$ Nesiotobacter exalbescens; ${ }^{\mathrm{f}}$ Rhodopseudomonas palustris; ${ }^{\mathrm{g}}$ Stappia stellulata.

\begin{tabular}{llcc}
\hline Gene & \multicolumn{1}{c}{ Function } & $\begin{array}{c}\text { Percent of } \\
\text { identity }\end{array}$ & $\begin{array}{c}\text { Accession } \\
\text { number }\end{array}$ \\
\hline$D d d D$ & L-carnitine dehydratase & $70 \%^{\mathrm{a}}$ & KM819464 \\
$D d d T$ & BCCT transporter & $70 \%^{\mathrm{a}}$ & KM819465 \\
$D d d B$ & Alcohol dehydrogenase & $70 \%^{\mathrm{a}}$ & KM819466 \\
$D d d C$ & Methylmalonate-semialdehyde dehydrogenase & $56 \%^{\mathrm{a}}$ & KM819467 \\
$D d d R$ & Transcriptional regulator, LysR family protein & $53 \%^{\mathrm{a}}$ & KM819468 \\
\hline$D m d A$ & Aminomethyl transferase family protein & $24 \%^{\mathrm{b}}$ & KU521525 \\
$D m d B$ & Acyl-CoA synthetase & $30 \%^{\mathrm{b}}$ & KU521526 \\
$D m d C$ & MMPA-CoA dehydrogenase & $43 \%^{\mathrm{b}}$ & KU521527 \\
$D m d D$ & MTA-CoA hydratase & $32 \%^{\mathrm{b}}$ & KU521528 \\
\hline$A l m a 1$ & Hypothetical Almal ortholog & $99 \%^{\mathrm{c}}$ & KU521524 \\
\hline$t d a A$ & Transcriptional regulator, LysR family protein & $66 \%^{\mathrm{d}}$ & KU760700 \\
$t d a B$ & Glutathione S-transferase domain protein & $67 \%^{\mathrm{d}}$ & KU760701 \\
$t d a C$ & Prephenate dehydratase & $67 \%^{\mathrm{d}}$ & KU760702 \\
$t d a D$ & Acyl-CoA thioester hydrolase & $81 \%^{\mathrm{d}}$ & KU760703 \\
$t d a E$ & Acyl-CoA dehydrogenase & $69 \%^{\mathrm{d}}$ & KU760704 \\
$t d a F$ & Phosphopantothenoylcysteine decarboxylase & $72 \%^{\mathrm{d}}$ & KU760705 \\
$c y s I$ & Sulfite reductase hemoprotein beta-component & $76 \%^{\mathrm{e}}$ & KU760706 \\
$m a l Y$ & Cystathione beta-lyase & $68 \%^{\mathrm{e}}$ & KU760707 \\
$p a a I$ & Phenylacetate-CoA oxygenase & $59 \%^{\mathrm{f}}$ & KU760708 \\
$p a a J$ & Phenylacetate-CoA oxygenase, PaaJ subunit & $73 \%^{\mathrm{g}}$ & KU760709 \\
$p a a K$ & Phenylacetic acid degradation oxidoreductase & $57 \%^{\mathrm{g}}$ & KU760710 \\
\hline
\end{tabular}




\section{2}

523

524

525

526

527

528

529

530

531

532

533

534

Table 2: Summary of Pseudovibrio isolated or sequenced from corals, accession numbers are displayed when available (NA: not available).

\begin{tabular}{ccccc}
\hline Host & Location & Method & Reference & Accession numbers \\
\hline Acropora palmata & Panama & Amplicon & (Sunagawa et al. 2010) & GU118050, GU118108, GU119014 \\
Porites astreoides & Panama & Amplicon & (Sunagawa et al. 2010) & GU118050, GU118108, GU119014 \\
Acropora cervicornis & Panama & Amplicon & (Sunagawa et al. 2010) & GU118050, GU118108, GU119014 \\
Montastrea franksi & Panama & Amplicon & (Sunagawa et al. 2010) & GU118050, GU118108, GU119014 \\
Tubastraea coccinea & China & Amplicon & (Yang et al. 2013) & JF925014 \\
Pseudopterogorgia americana & Puerto Rico & Isolated & (Vizcaino et al. 2010) & GQ406787, GQ406798, GQ391966, GQ406786 \\
Platygyra carnosus & Hong Kong & Isolated & (Chiu et al. 2012) & JF411474, JF411466, JF411439, JF411464 \\
Oculina patagonica & Israel & Isolated & (Koren \& Rosenberg 2006) & DQ416557, AY654776 \\
Montastrea anularis & Florida & Isolated & (Rypien et al. 2010) & FJ952798, FJ952774, FJ952804 \\
Sinularia sp. & Indonesia & Isolated & (Sulistiyani et al. 2010) & NA \\
Acropora almata & Florida & Isolated & (Ritchie 2006) & DQ530540 \\
Sarcophyton sp. & Java & Isolated & (Sabdono \& Radjasa 2006) & NA \\
Oculina patagonica & Israel & Isolated & (Nissimov et al. 2009) & NA \\
Lobophytum sp. & Taiwan & Isolated & (Chen et al. 2012) & JQ342682, JQ342695, JQ342696, JQ342697 \\
Hard coral & Florida & Isolated & (Bondarev et al. 2013) & CP003147 \\
\hline
\end{tabular}

\section{References}

Alcolombri U, Ben-Dor S, Feldmesser E, Levin Y, Tawfik DS, and Vardi A. 2015. Identification of the algal dimethyl sulfide-releasing enzyme: a missing link in the marine sulfur cycle. Science 348:1466-1469.

Apprill A, Marlow HQ, Martindale MQ, and Rappe MS. 2009. The onset of microbial associations in the coral Pocillopora meandrina. ISME J 3:685-699.

Bankevich A, Nurk S, Antipov D, Gurevich AA, Dvorkin M, Kulikov AS, Lesin VM, Nikolenko SI, Pham S, Prjibelski AD, Pyshkin AV, Sirotkin AV, Vyahhi N, Tesler G, Alekseyev MA, and Pevzner PA. 2012. SPAdes: a new genome assembly algorithm and its application to single-cell sequencing. Journal of Computational Biology 19:455-477. doi: $10.1089 / \mathrm{cmb} .2012 .0021$

Bellwood DR, and Hughes TP. 2001. Regional-scale assembly rules and biodiversity of coral reefs. Science 292:1532-1535. 
535

536

537

538

539

540

541

542

543

544

545

546

547

548

549

550

551

552

553

554

555

556

557

558

559

560

561

562

563

564

565

566

567

568

569

570

571

572

573

574

575

576

577

578
Ben-Haim Y, Thompson FL, Thompson CC, Cnockaert MC, Hoste B, Swings J, and Rosenberg E. 2003. Vibrio coralliilyticus sp. nov., a temperature dependent pathogen of the coral Pocillopora damicornis. IJSEM 53:309-315.

Bondarev V, Richter M, Romano S, Piel J, Schwedt A, and Schulz-Vogt HN. 2013. The genus Pseudovibrio contains metabolically versatile bacteria adapted for symbiosis. Environ Microbiol 15:2095-2113.

Bourne D, and Munn C. 2005. Diversity of bacteria associated with the coral Pocillopora damicornis from the Great Barrier Reef. Environ Microbiol 7:1162-1174.

Bourne DG, Dennis PG, Uthicke S, Soo RM, Tyson GW, and Webster NS. 2013. Coral reef invertebrate microbiomes correlate with the presence of photosymbionts. ISME $J$ In press. 10.1038/ismej.2012.172

Brinkhoff T, Bach G, Heidorn T, Liang L, Schlingloff A, and Simon M. 2004. Antibiotic production by a Roseobacter clade-affiliated species from the German Wadden Sea and its antagonistic effects on the indigenous isolates. Appl Environ Microbiol 70:2560-2565.

Brock NL, Nikolay A, and Dickschat JS. 2014. Biosynthesis of the antibiotic tropodithietic acid by the marine bacterium Phaeobacter inhibens. Chemical Communications 50:5487-5489. 10.1039/C4CC01924E

Bruhn JB, Gram L, and Belas R. 2007. Production of antibacterial compounds and biofilm formation by Roseobacter species are influenced by culture conditions. Appl Environ Microbiol 73:442-450.

Bruhn JB, Nielsen KF, Hjelm M, Hansen M, Bresciani J, Schulz S, and Gram L. 2005. Ecology, inhibitory activity, and morphogenesis of a marine antagonistic bacterium belonging to the Roseobacter clade. Appl Environ Microbiol 71:7263-7270.

Bruno JF, Selig ER, Casey KS, Page CA, Willis BL, Harvell DC, Sweatman H, and Melendy AM. 2007. Thermal stress and coral cover as driver of coral disease outbreaks. PLoS Biol 5:e124. 10.1371/journal.pbio.0050124

Cane DE, Wu Z, and van Epp JE. 1992. Thiotropocin biosynthesis. Shikimate origin of a sulfurcontaining tropolone derivative. J Am Chem Soc 114:8479-8483.

Chen Y-H, Kuo J, Sung P-J, Chang Y-C, Lu M-C, Wong T-Y, Liu J-K, Weng C-F, Twan W-H, and Kuo F-W. 2012. Isolation of marine bacteria with antimicrobial activities from cultured and field-collected soft corals. World Journal of Microbiology and Biotechnology 28:3269-3279. 10.1007/s11274-012-1138-7

Chiu JMY, Li S, Li A, Po B, Zhang R, Shin PKS, and Qiu J-W. 2012. Bacteria associated with skeletal tissue growth anomalies in the coral Platygyra carnosus. FEMS Microbiology Ecology 79:380-391. 10.1111/j.1574-6941.2011.01225.x

Dang HY, and Lovell CR. 2000. Bacterial primary colonization and early ssuccession on surfaces in marine waters as determined by amplified rRNA gene restriction analysis and sequences analysis of 16S rRNA genes. Appl Environ Microbiol 66:467-475.

Enticknap JJ, Kelly M, Peraud O, and Hill RT. 2006. Characterization of a culturable Alphaproteobacterial symbiont common to many marine sponges and evidence for vertical transmission via sponge larvae. Appl Environ Microbiol.

Fuse H, Takimura O, Murakami K, Yamaoka Y, and Omori T. 2000. Utilization of dimethyl sulfide as a sulfur source with the aid of light by Marinobacterium sp. strain DMS-S1. Appl Environ Microbiol 66:5527-5532. 
579

580

581

582

583

584

585

586

587

588

589

590

591

592

593

594

595

596

597

598

599

600

601

602

603

604

605

606

607

608

609

610

611

612

613

614

615

616

617

618

619

620

621

622

Fusetani N, Toyoda T, Asai N, Matsunaga S, and Maruyama T. 1996. Montiporic acids A and B, cytotoxic and antimicrobial polyacetylene carboxylic acids from eggs of the scleractinian coral Montipora digitata. J Nat Prod 59:796-797.

Garren M, and Azam F. 2010. New method for counting bacteria associated with coral mucus. Appl Environ Microbiol 76:6128-6133.

Geffen Y, Ron EL, and Rosenberg E. 2009. Regulation of release of antibacterials from stressed scleractinians corals. FEMS Microbiology Letters 295:103-109.

Geffen Y, and Rosenberg E. 2005. Stress-induced rapid release of antibacterials by scleractinian corals. Mar Biol 146:931-935.

Geng H, and Belas R. 2010. Expression of tropodithietic acid biosynthesis is controlled by a novel autoinducer. $J$ Bacteriol 192:4377-4387.

Geng H, Bruhn JB, Nielsen KF, Gram L, and Belas R. 2008. Genetic dissection of tropodithietic acid biosynthesis by marine roseobacters. Appl Environ Microbiol 74:1535-1545.

Gochfeld D, and Aeby GS. 2008. Antibacterial chemical defences in Hawaiian corals provide possible protection from disease. MEPS 362:119-128.

Heron SF, Willis BL, Skirving WJ, Eakin M, Page CA, and Miller IR. 2010. Summer hot snaps and winter conditions: modelling white syndrome outbreaks on Great Barrier Reef corals. PLoS One 5:e12210. 10.1371/journal.pone.0012210

Hjelm M, Bergh O, Riaza A, Nielsen J, Melchiorsen J, Jensen S, Duncan H, Ahrens P, Birkbeck H, and Gram L. 2004. Selection and identification of autochthonous potential probiotic bacteria from turbot larvae (Scophthalmus maximus) rearing units. Syst Appl Microbiol 27:360-371.

Howard EC, Henriksen JR, Buchan A, Reisch CR, Burgmann H, Welsh R, Ye W, González JM, Mace K, Joye SB, Kiene RP, Whitman WB, and Moran MA. 2006. Bacterial taxa that limit sulfur flux from the ocean. Science 314:649-652.

Kennedy J, Baker P, Piper C, Cotter PD, Walsh M, Mooij MJ, Bourke MB, Rea MC, O'Connor PM, Ross RP, Hill C, O'Gara F, Marchesi JR, and Dobson ADW. 2009. Isolation and analysis of bacteria with antimicrobial activities from the marine sponge Haliclona simulans collected from Irish waters. Mar Biotechnol 11:384-396.

Kiene RP, Linn LJ, Gonzalez J, Moran MA, and Bruton JA. 1999. Dimethylsulfoniopropionate and methanethiol are important precursors of methionine and protein-sulfur in marine bacterioplankton. Appl Environ Microbiol 65:4549-4558.

Knowlton N. 2001. Coral reef biodiversity - habitat size matters. Science 292:1493-1494.

Kodani S, Sato K, Higuchi T, Casareto BE, and Suzuki Y. 2013. Montiporic acid D, a new polyacetylene carboxylic acid from scleractinian coral Montipora digitata. Natural Product Research 27:1859-1862.

Koh EGL. 1997. Do scleractinian corals engage in chemical warfare against microbes. Journal of Chemical Ecology 23:379-398.

Koren O, and Rosenberg E. 2006. Bacteria associated with mucus and tissues of the coral Oculina patagonica in summer and winter. Appl Environ Microbiol 75:254-259.

Lema KA, Willis BL, and Bourne DG. 2012. Corals form characteristic associations with symbiotic nitrogen-fixing bacteria. Appl Environ Microbiol 78:3136-3144.

Lesser MP, Mazel CH, Gorbunov MY, and Falkowski PG. 2004. Discovery of symbiotic nitrogen-fixing cyanobacteria in corals. Science 305:997-1000. 
623

624

625

626

627

628

629

630

631

632

633

634

635

636

637

638

639

640

641

642

643

644

645

646

647

648

649

650

651

652

653

654

655

656

657

658

659

660

661

662

663

664

665

666

667

Littman RA, Willis BL, Pfeffer C, and Bourne DG. 2009. Diversity of coral-associated bacteria differ with location but not species for three Acroporids on the Great Barrier Reef. FEMS Microbiology Letters 68:152-163.

Marchesi JR, Sato T, Weightman AJ, Martin AT, Fry JC, and Wade WG. 1998. Design and evaluation of useful bacterium-specific primers that amplify genes coding for 16S rRNA. Appl Environ Microbiol 64:795-799.

Maynard JA, Anthony KRN, Harvell DC, Burgman MA, Beeden R, Sweatman H, Heron SF, Lamb JB, and Willis BL. 2011. Predicting outbreaks of a climate-driven coral disease in the Great Barrier Reef. Coral Reefs 30:485-495.

Miller TR, Hnilicka K, Dziedzic A, Desplats P, and Belas R. 2004. Chemotaxis of Silicibacter sp. strain TM1040 toward dinoflagellate products. Appl Environ Microbiol 70:46924701.

Moran MA, González JM, and Kiene RP. 2003. Linking a bacterial taxon to sulfur cycling in the sea: studies of the marine Roseobacter group. Geomicrobiol J 20:375-388.

Moran MA, Reisch CR, Kiene RP, and Whitman WB. 2012. Genomic insights into bacterial DMSP transformations. Annual Review of Marine Science 4:523-542.

Nissimov J, Rosenberg E, and Munn CB. 2009. Antimicrobial properties of resident coral mucus bacteria of Oculina patagonica. FEMS Microbiol Lett 292:210-215.

O'Halloran JA, Barbosa TM, Morrissey JP, Kennedy J, O'Gara F, and Dobson ADW. 2011. Diversity and antimicrobial activity of Pseudovibrio spp. from Irish marine sponges. $J$ Appl Microb 110:1495-1508.

Olson ND, Ainsworth TD, Gates RD, and Takabayashi M. 2009. Diazotrophic bacteria associated with Hawaiian Montipora corals: diversity and abundance in correlation with symbiotic dinoflagellates. $J$ Exp Mar Biol and Ecol 371:140-146.

Pauley G. 1997. Diversity and distribution of reef organisms. In: Birkeland C, ed. Life and death of coral reefs. New York: Chapman and Hall, 298-345.

Penesyan A, Tebben J, Lee M, Thomas T, Kjelleberg S, Harder T, and Egan S. 2011. Identification of the antibacterial compound produced by the marine epiphytic bacterium Pseudovibrio sp. D323 and related sponge-associated bacteria. Mar Drugs 9:1391-1402.

Porsby CH. 2010. Antagonism of Roseobacter clade bacteria against pathogenic bacteria PhD Thesis. Technical University of Denmark.

Radjasa OK, Wiese J, Sabdono A, and J.F. I. 2008. Coral as source of bacteria with antimicrobial activity. $J$ Coastal Development 11:121-130.

Raina JB, Dinsdale EA, Willis BL, and Bourne DG. 2010. Do the organic sulfur compounds DMSP and DMS drive coral microbial associations? Trends in Microbiology 18:101-108.

Raina JB, Tapiolas D, Willis BL, and Bourne DG. 2009. Coral-associated bacteria and their role in the biogeochemical cycling of sulfur. Appl Environ Microbiol 75:3492-3501.

Raina JB, Tapiolas DM, Forêt S, Lutz A, Abrego D, Ceh J, Seneca F, Clode PL, Bourne DG, Willis BL, and Motti CA. 2013. DMSP biosynthesis by an animal and its role in coral thermal stress response. Nature 502:677-680.

Reisch CR, Stoudemayer MJ, Varaljay VA, Amster IJ, Moran MA, and Whitman WB. 2011. Novel pathway for assimilation of dimethylsulfoniopropionate widespread in marine bacteria. Nature 473:208-211.

Ritchie KB. 2006. Regulation of microbial populations by coral surface mucus and mucusassociated bacteria. Marine Ecology Progress Series 322:1-14. 
668

669

670

671

672

673

674

675

676

677

678

679

680

681

682

683

684

685

686

687

688

689

690

691

692

693

694

695

696

697

698

699

700

701

702

703

704

705

706

707

708

709

710

711

712

Ritchie KB, and Smith GW. 2004. Microbial communities of coral surface mucopolysaccharide layer. In: Rosenberg E, and Loya Y, eds. Coral health and disease. Berlin: SpringerVerlag, 259-263.

Rohwer F, Breitbart M, Jara J, Azam F, and Knowlton N. 2001. Diversity of bacteria associated with the Caribbean coral Monastera franksi. Coral Reefs 20:85-91.

Rypien KL, Ward JR, and Azam F. 2010. Antagonistic interactions among coral-associated bacteria. Environmental Microbiology 12:28-39.

Sabdono A, and Radjasa OK. 2006. Antifouling activity of bacteria associated with soft coral Sarcophyton sp. against marine biofilm-forming bacteria. J Coastal Development 10:5562.

Seeman T. 2014. Prokka: rapid prokariotic genome annotation. Bioinformatics 30:2068-2069.

Sertan-de Guzman AA, Predicala RZ, Bernardo EB, Neilan BA, Elardo SP, Mangalindan GC, Tasdemir D, Ireland CM, Barraquio WL, and Concepcion GP. 2007. Pseudovibrio denitrificans strain Z143-1, a heptylprodigiosin-producing bacterium isolated from a Philippine tunicate. FEMS Microbiol Lett 277:188-196.

Shieh WY, Lin Y, and Jean WD. 2004. Pseudovibrio denitrificans gen. nov., sp. nov., a marine, facultative anaerobic, fermentative bacterium capable of denitrification. IJSEM 54:23072312.

Shnit-Orland M, and Kushmaro A. 2008. Coral mucus bacteria as a source of antibacterial activity. Proceedings of the $11^{\text {th }}$ International Coral Reef Symposium:257-259.

Shnit-Orland M, and Kushmaro A. 2009. Coral mucus-associated bacteria: a possible first line of defence. FEMS Microbiol Lett 67:371-380.

Simo R. 2001. Production of atmospheric sulfur by oceanic plankton: biogeochemical, ecological and evolutionary links. Trends in Ecology and Evolution 16:287-294.

Sulistiyani S, Nugraheni A, Radjasa OK, Sabdono A, and Khoeri MM. 2010. Antibacterial activities of bacterial symbionts of soft coral Sinularia sp. against tuberculosis bacteria. $J$ Coastal Development 14:45-50.

Sunagawa S, Woodley CM, and Medina M. 2010. Threatened corals provide underexplored microbial habitats. PLoS One 5:e9554. 10.1371/journal.pone.0009554

Sussman M, Willis BL, Victor S, and Bourne DG. 2008. Coral pathogens identified for white syndrome epizootic in the indo-pacific. PLoS One 3:e2393.

Tapiolas DM, Raina JB, Lutz A, Willis BL, and Motti CA. 2013. Direct measurement of dimethysulfoniopropionate (DMSP) in reef-building corals using quantitative nuclear magnetic resonance (qNMR) spectroscopy. JEMBE 443:85-89.

Thiel V, Brinkhoff T, Dickschat JS, Wickel S, Grunenberg J, Wagner-Dobler I, Simon M, and Schulz S. 2010. Identification and biosynthesis of tropone derivatives and sulfur volatiles produced by bacteria of the marine Roseobacter clade. Org Biomol Chem 2010:234-246.

Thiel V, and Imhoff JF. 2003. Phylogenetic identification of bacteria with antimicrobial activities isolated from Mediterranean sponges. Biomolecular Engineering 20:421-423.

Todd JD, Rogers R, Li YG, Wexler M, Bond PL, Sun L, Cuurson ARJ, Malin G, Steinke M, and Johnston AWB. 2007. Structural and regulatory genes required to make the gas dimethylsulfide in bacteria. Science 315:666-669.

Ushijima B, Smith A, Aeby GS, and Callahan SM. 2012. Vibrio owensii induces the tissue loss disease Montipora white syndrome in the Hawaiin reef coral Montipora capitada. PLoS One 7:10. 
713

714

715

716

717

718

719

720

721

722

723

724

725

726

727

728

729

730

731

732

733

734

735

736

737
Vidal-Dupiol J, Ladriere O, Destoumieux-Garzon D, Sautiere PE, Meistertzheim AL, Tambutte E, Tambutte S, Duval D, Foure L, Adjeroud M, and Mitta G. 2011. Innate immune responses of a scleractinian coral to vibriosis. J Biol Chem 286:22688-22698.

Vizcaino MI. 2011. The chemical defense of Pseudopternogorgia americana: a focus on the antimicrobial potential of a Pseudovibrio sp. PhD Thesis. University of South Carolina.

Vizcaino MI, Johnson WR, Kimes NE, Williams K, Torralba M, Nelson KE, Smith GW, Weil E, Moeller PDR, and Morris PJ. 2010. Antimicrobial resistance of the coral pathogen Vibrio coralliilyticus and sister phylotypes isolated from a diseased Octocoral. Microb Ecol 59:646-657.

Wagner-Dobler I, and Biebl H. 2006. Environmental biology of the marine Roseobacter lineage. Annual Reviews Of Microbiology 60:255-280.

Webster NS, and Hill RT. 2001. The culturable microbial community of the Great Barrier Reef sponge Rhopaloeides odorabile is dominated by an Alphaproteobacterium. Marine Biology 138:843-851.

Willis BL, Page CA, and Dinsdale EA. 2004. Coral disease on the Great Barrier Reef. In: Rosenberg E, and Loya Y, eds. Coral health and disease: Springer, 69-104.

Wilson MZ, Wang R, Gitai Z, and Seyedsayamdost MR. 2016. Mode of action and resistance studies unveil new roles for tropodithietic acid as an anticancer agent and the $\gamma$-glutamyl cycle as a proton sink. Proceedings of the National Academy of Sciences 113:1630-1635. $10.1073 /$ pnas. 1518034113

Yang S, Sun W, Zhang F, and Li Z. 2013. Phylogenetically Diverse Denitrifying and AmmoniaOxidizing Bacteria in Corals Alcyonium gracillimum and Tubastraea coccinea. Marine Biotechnology 15:540-551. 10.1007/s10126-013-9503-6 